\title{
Pelatihan Pembuatan Ransum Unggas Menggunakan Bahan Pakan Lokal Kecamatan Weda Selatan Kabupaten Halmahera Tengah
}

\section{Training for Making Poultry Ranks using Local Feed Ingredients of Sub District Weda Selatan District Halmahera Tengah}

\author{
Emy Saelan ${ }^{1, a}$ dan Sri Lestari ${ }^{1}$ \\ ${ }^{1}$ Fakutas Pertanian Prodi Peternakan Universitas Khairun, Ternate \\ aemail: emysaelan@gmail.com
}

\begin{abstract}
Abstrak
Ransum merupakan faktor yang paling menentukan dalam usaha peternakan, dimana ketersediaan ransum harus terpenuhi guna menunjang pertumbuhan dan produksi yang diharapkan. Tujuan dari program Pelatihan Pembuatan Ransum Unggas Menggunakan Bahan Pakan Lokal adalah untuk membantu peternak agar dapat membuat ransum unggas dengan menggunakan bahan pakan lokal, meningkatkan keterampilan dan pengetahuan peternak dalam pembuatan ransum unggas khususnya ayam buras dan itik, sehingga dapat meningkatkan produktifitas ternaknya yaitu produksi daging dan telur serta meningkatkan pendapatan peternak. Target luaran yang ingin dicapai melalui Program PKM Kubermas Tematik adalah peternak dapat membuat dan meramu ransum unggas khususnya ransum itik dan ayam kampung, meningkatkan keterampilan peternak dalam membuat dan mengolah pakan, manajemen pemeliharaan, pengolahan ransum itik, serta luaran fisik berupa rumah produksi pembuatan ransum unggas. Hasil kegiatan PKM menunjukkan peternak tidak tergantung lagi pada ransum pabrikan, kelompok peternak binaan dapat menyediakan ransum bagi peternak pemula, sehingga peningkatan populasi dan produktifitas terutama telur dan daging dapat tercapai secara optimal.
\end{abstract}

Kata Kunci: Ransum, ayam kampung, itik, telur, daging, pakan lokal.

\begin{abstract}
The ration is the most decisive factor in livestock business, where the availability of rations must be met to support the expected growth and production. The of Training program for Poultry Ration Making Using Local Feed Ingredients to help breeders make poultry rations using local feed ingredients, improve skills and knowledge of farmers in making poultry rations, especially native chickens and ducks, so as increase their livestock productivity, namely meat production and eggs and increase the income of farmers. The output target to be achieved through the Tematik Kubermas PKM Program is that breeders can make and mix poultry rations, especially ducks and native chickens, breeders' skills in making and processing feed, maintenance management, duck ration processing, and physical output in the form of production house for making poultry rations. The results of PKM activities show that breeders are no longer dependent on manufactured rations, assisted farmer groups can provide rations for novice breeders, so that population and productivity increases, especially eggs and meat, can be achieved optimally.
\end{abstract}

Keywords: Rations, native chickens, ducks, eggs, meat, local feed 


\section{Pendahuluan}

Kabupaten Halmahera Tengah merupakan daerah untuk pengembangan ternak unggas khususnya ayam kampung dan itik. Hal ini didukung oleh potensi sumberdaya lokal yang tersedia terutama bahan pakan unggas yang berasal dari hasilhasil pertanian di daerah tersebut. Kabupaten Halmahera Tengah merupakan salah satu kabupaten dengan populasi ternak unggas 6.861 ekor ayam kampung pada tahun 2017 (BPS, 2017) meningkat menjadi 10.987 ekor ayam kampug pada tahun 2018 (BPS, 2019) dan ternak itik 230 ekor pada tahun 2017 meningkat menjadi 586 ekor pada tahun 2018.

Pertumbuhan populasi ayam kampung dan itik di Kecamatan Weda Selatan tergolong masih sangat rendah. Hal ini disebabkan pengetahuan peternak dalam pembuatan ransum khususnya ayam kampung dan itik sangat minim dan terbatas. Guna untuk meningkatkan meningkatkan produktifitas ternak pakan merupakan salah satu faktor utama yang menentukan keberhasilan suatu usaha peternakan. Produksi hasil pertanian di Kecamatan Weda Selatan khususnya di Desa Kluting Jaya terutama jagung, ubi, padi dan kacang mengalami peningkatan dari tahun ke tahun. Hasil-hasil pertanian tersebut merupakan bahan utama untuk pembuatan ransum unggas khususnya ayam kampung dan itik. Ternak itik penggunaan limbah pertanian seperti sayur-suyuran dapat menghemat biaya pakan. Limbah sayur-sayuran (kol, sawi. Caisim dan kangkung) banyak dimanfaatkan untuk pakan ternak terutama ternak kambing, kelinci dan itik. Hai ini sangat menguntungkan karena selain mengurangi jumlah sampah, juga mengurangi biaya ransum untuk ternak (Rusmana dkk., 2007).

Guna meningkatkan pengetahuan peternak akan pembuatan pakan unggas menggunakan bahan pakan lokal, maka perlu dilakukan pelatihan kepada peternak. Pelatihan ini diharapkan peternak dapat membuat ransum unggas yaitu ayam kampung dan itik. Keterampilan peternak dalam meramu bahan pakan menjadi ransum akan sangat bermanfaat untuk meningkatkan ketrampilan formulasi ransum sesuai dengan kebutuhan ternak sehingga dapat meningkatkan produksi berupa daging dan telur. Pelaksanaan Kegiatan Program Kemitraan Masyarakat Kubermas Tematik Universtas Khairun, yang melibatkan mahasiswa peserta Kubermas berperan aktif dalam membantu peternak meningkatkan pemahanan dan keterampilan meramu dan membuat ransum unggas yaitu ayam kampung dan itik dengan memanfaatkan potensi sumberdaya lokal yang ada di daerah tersebut.

Program Kegiatan Kemitraan Masyarakat Kubermas Tematik Universtas Khairun dilaksanakan dengan tujuan meningkatkan keterampilan dan pengetahuan peternak dalam pembuatan ransum unggas yaitu ayam kampung dan itik, sehingga dapat meningkatkan produktifitas ternaknya yaitu produksi daging dan telur.

\section{Metode Pelaksanaan}

Metode pelaksanaan Kegiatan Program Kemitraan Masyarakat Kubermas Tematik Universitas Khairun di Kecamatan Weda Selatan Kabupaten Halmahera Tengah dalam bentuk sosialisasi dan pelatihan dengan cara metode diskusi dan praktek langsung pembuatan pakan di lokasi peternakan. Metode ini dikatakan berhasil apabila sasaran atau peternak memahami dan mampu menerapkan teori yang diperoleh melalui praktik secara langsung. Metode yang dipakai dalam pelaksanaan Program PKM Kubermas Tematik yaitu:

\section{Metode Non Fisik yaitu:}

> Observasi lapangan; Observasi perdana dilakukan pada tanggal 1 Maret 2020, hal ini diyakini akan mempermudah mahasiswa kubermas ketika merumuskan program kerja mereka.

$>$ Identifikasi potensi dan masalah. Hal ini dilakukan untuk mengenal karakteristik desa secara komprehensif. Hasil dari indentifikasi akan dibuat catatan guna diserahkan ke pemerintah desa sebagai bahan evaluasi. 
> Wawancara. Untuk memperoleh informasi lebih detail dan murni, kami juga memakai metode wawancara ke tokoh masyarakat, tokoh agama, tokoh pemuda, serta unsur-unsur yang ada di dalam desa.

\section{Metode Fisik}

Metode fisik yang dilakukan meliputi demonstrasi pembuatan dan penuyusan ransum unggas untuk itik dan ayam kampung dengan menggunakan bahan pakan lokal yang ada di Desa Kluting Jaya, serta pengemasan dan cara penyimpanan ransum yang telah dibuat.

\section{Hasil dan Pembahasan}

\section{A. Kondisi Desa}

Desa adalah satu kesatuan masyarakat yang memiliki batas-batas wilayah yang berwenang mengatur dan mengurus masyarakat setempat, berdasarkan asal-usul dan adat-istiadat setempat yang diakui dan dihormati dalam sistem pemerintahan Negara Kesatuan Republik Indonesia. Desa Kluting Jaya berada di wilayah Kecamatan Weda Selatan Kabupaten Halmahera Tengah. Sebelum tahun 2009 wilayah Desa Kluting Jaya sangat luas yaitu mencakup desa sumber sari yang dulunya berstatus Dusun II dimekarkan menjadi Desa Sumber Sari

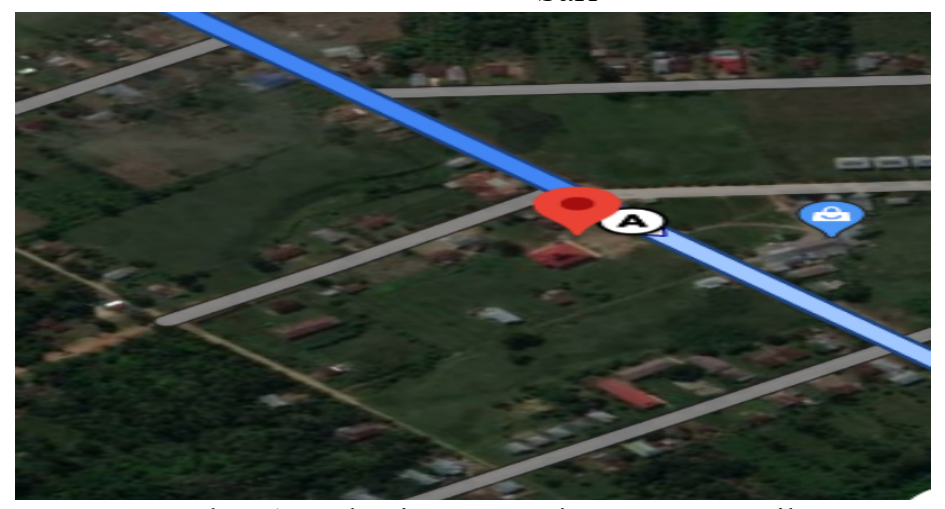

Gambar 1. Lokasi PKM Kubermas Tematik

Desa kluting jaya secara administratif termasuk dalam wilayah kecamatan Weda Selatan Kabupatan Halmahera Tengah terletak disebelah selatan Kabupaten Halmahera Tengah dengan jarak $38 \mathrm{~km}$ dari Ibu Kota Kabupaten. Jarak Desa Kluting Jaya dengan kantor Bupati 38 km, waktu tempuh menuju pusat kecamatan sekitar 15 menit dengan kendaraan motor/sepeda, sedangkan waktu tempuh Desa Kluting Jaya ke Ibu Kota Kabupaten Weda sekitar 2 jam.

\section{B. Topografi dan Jenis Tanah}

Desa Kluting Jaya secara topografi termasuk daerah perbukitan dengan ketinggian $50 \mathrm{~s} / \mathrm{d} 100 \mathrm{~m}$ di atas permukaan air laut (dpl), sehingga tergolong rendah, suhu di daerah ini cukup bervariasi antara $24^{\circ} \mathrm{C}$ saat paling dingin dan $35^{\circ} \mathrm{C}$ paling panas. Jenis tanah wilayah Desa Kluting Jaya sebagaian besar adalah andisol. Sifat tanah andisol adalah bersolom tebal/dalam dan berwarna kuning terang makin dalam makin terang. Tektur litany lity loam dengan kadar liat kurang dari $30 \%$. Kepekaan tanah andisol terhadap erosi cukup tinggi, keasamanya bermacam-macam, dan bahan organiknya rendah.

\section{Sistem Usah Tani}

Jenis komoditas yang paling banyak ditanam adalah pala sedangkan untuk jenis komoditas perkebunan paling banyak kelapa dan coklat. Pohon kelapa ditanam oleh petani, sebagian diambil buahnya, namun sebagian besar diolah menjadi minyak kelapa. Jenis komoditas kehutanan dan perkebunan ini mempunyai rotasi lebih dari satu tahun. Jenis komoditas pertanian yang ada di Desa Kluting Jaya terdiri dari padi, jeruk, tanaman sayuran, buah naga dan palawija.

\section{Sosialisasi Program}

Kegiatan sosialisasi PKM dilakukan dengan tujuan untuk menyamakan presepsi antara pelaksana program kegiatan PKM 
dengan masyarakat, sehingga tercapai tujuan yang dilaksanakan. Pelaksanaan sosialisasi mengikutsertakan masyarakat khususnya peternak unggas, aparatur Desa, dan perserta KUBERMAS TEMATIK Universitas Khairun. Kelompok ternak yang mengikuti kegiatan sosialisasi ini terdiri dari dari 2 kelompok mitra yaitu kelompok Mitra Ternak Entok Mandiri dan Kelompok Ternak Ayam Sejahtera

Hasil dari sosialisasi menunjukkan antusias masyarakat yang sangat tinggi, dimana banyak masyarakat yang dulumya beternak sebagai usaha sambilan dan tabungan terpaksa harus berhenti karena kendala pakan dan penyakit yang menyerang ternak. Sosialisasi ini menghasilkan keinginan masyarakat untuk kembali beternak karena dengan sosialisasi yang disampaikan dapat membuka wawasan masyarakat bahwa ketersediaan pakan untuk unggas tidak perlu menggunakan pakan pabrikan atau tergantung dari pakan komersil, tetapi peternak dapat membuat sendiri pakan tersebut. Bahan pakan pun tersedia di Desa Kluting Jaya.

\section{Pelatihan Pembuatan Ransum} Unggas

Kegiatan Pelatihan Pembuatan Ransum Unggas Menggunakan Bahan Pakan Lokal di Desa Kluting Jaya Kecamatan Weda Selatan Kabupaten $\begin{array}{lccr}\text { Halmahera } & \text { Tengah. } & \text { Teori } & \text { yang } \\ \text { disampaikan } & \text { dalam } & \text { kegiatan } & \text { ini }\end{array}$ menggunakan bahasa yang mudah dimengerti oleh peternak, sehingga peternak lebih mudah untuk menerima dan mempraktekannya. Materi yang telah disampaikan dilanjutkan dengan praktek secara langsung kepada peserta pelatihan.

Jahan et al. (2006) menyatakan bentuk fisik pakan adalah salah satu faktor yang mempengaruhi biaya produksi dan performa ternak. Beberapa bentuk fisik pakan unggas yaitu halus (mash), remah (crumble), dan pellet (North, 1978; Ichwan, 2003). Ransum itik dapat diberikan dalam bentuk pellet ataupun bentuk halus, dimana ransum pellet dapat diberikan secara kering sedangkan bentuk halus dapat diberikan dalam bentuk kering atau basah (Wahyu, 2004). Ransum itik umumnya diberikan dalam bentuk basah dengan cara menambahkan air dalam ransum sehingga membuat bahan ransum saling melekat. Ransum bentuk mash dikenal sebagai ransum bentuk halus yang mengandung zatzat makanan seimbang, dari penggilingan bahan-bahan makanan penyusun ransum dicampur bersama-sama. Ransum itik umumnya diberikan dalam bentuk basah dengan cara menambahkan air dalam ransum, sehingga membuat bahan ransum menjadi saling melekat (Anggorodi, 1995).

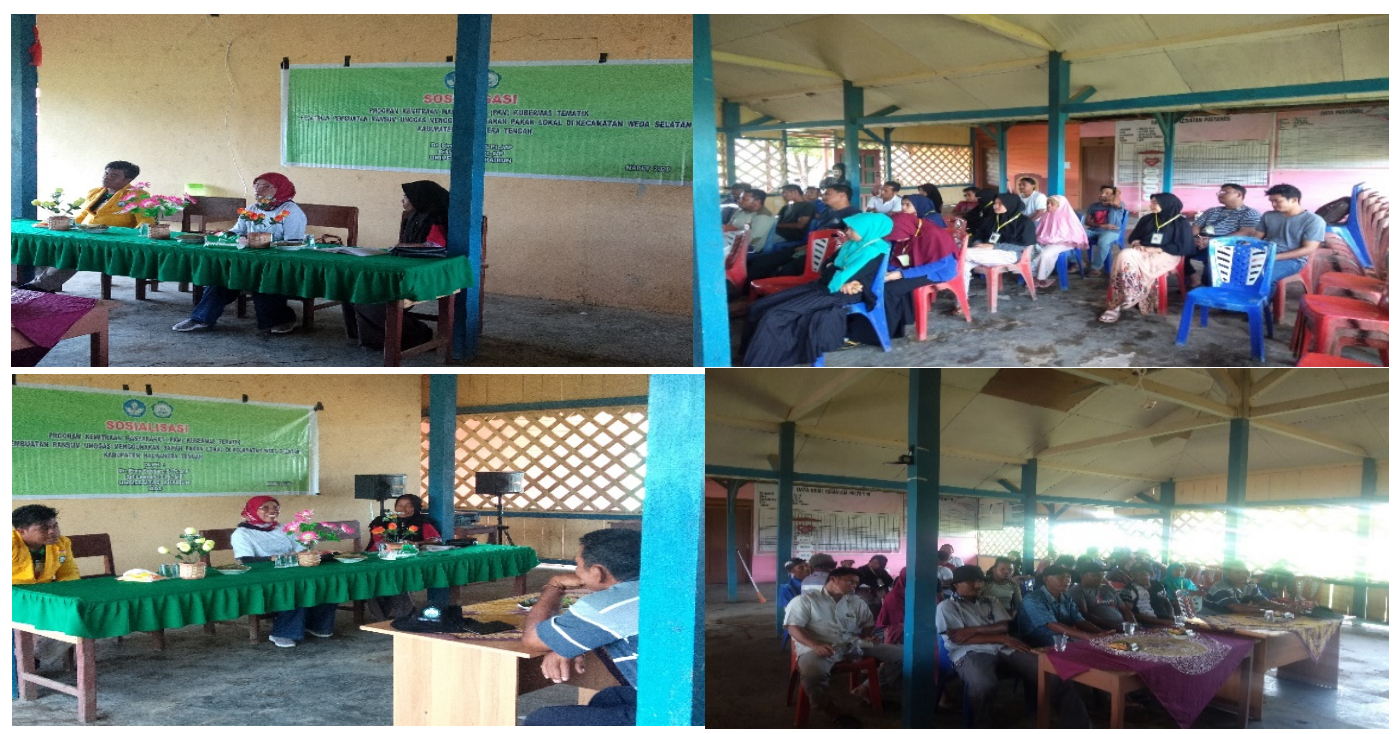

Gambar 2. Sosialisasi Program Kegiatam PKM Kubermas Tematik 


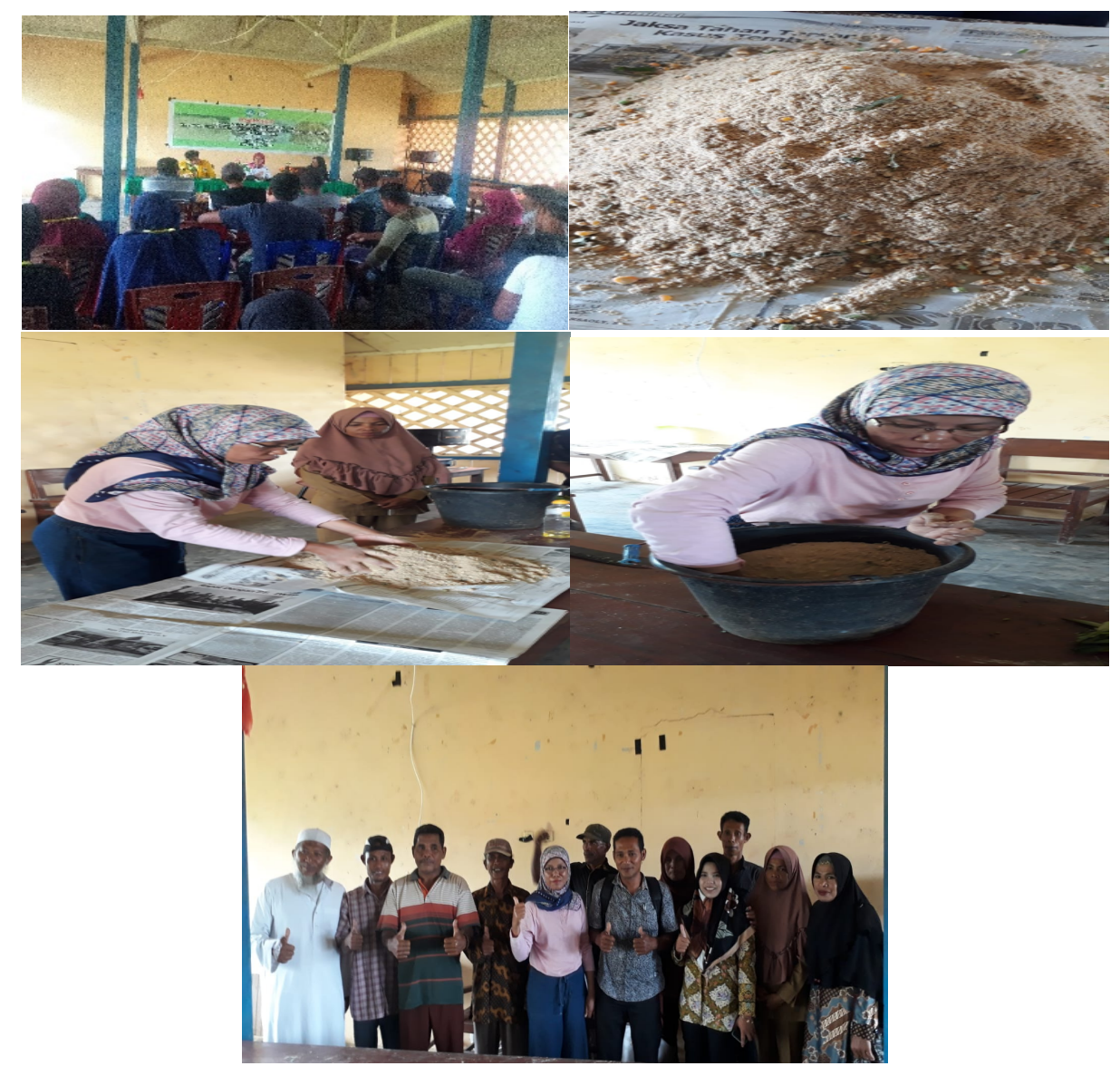

Gambar 3. Pelatihan Program Kegiatam PKM Kubermas Tematik dan Pelatihan Pembuatan Ransum Unggas

Kegiatan pelatihan pembuatan ransum unggas berupa demonstasi cara meramu bahan pakan menjadi ransum unggas yaitu itik dan ayam kampung. Bahan pakan yang digunakan dalam pelatihan terdiri dari: jagung kuning, dedak, tepung ikan, limbah sayuran (kangkung dan sawi), limbah tauge, bekicot dan minyak kelapa. Demonstrasi cara meramu atau mencampur bahan pakan menjadi ransum dilakukan dengan tujuan agar peternak dan mitra agar dapat membuat sendiri ransum ternaknya, sehingga nantinya tidak tergantung pada ransum pabrikan. Antusias peternak dan mitra dalam pelatihan sangat tinggi, hal ini dapat dilihat dimana masing-masing peternak dan mitra menyediakan bahan-bahan pakan yang ada di Desa Kluting Jaya untuk dibuat menjadi ransum.

Bahan baku penyusun ransum unggas terdiri dari sumber energi dan protein, yaitu jagung kuning, bungkil kedele, tepung ikan, dedak, bungkil kelapa, minyak kelapa, vitamin dan mineral. Bahan pakan hewani seperti tepung ikan harus ada di dalam ransum karena tepung ikan mengandung asam amino essensial seperti methionine dan lysine (Wahju, 2004). Formulasi penyusunan ransum unggas ini menggunakan metode Trial and Error atau metode Coba-coba, dengan kandungan Protein 19\% dan Energi Metabolisme 2800 $\mathrm{kkal} / \mathrm{kg}$. Kandungan nutrien ransum yang digunakan dalam kegiatan pelatihan ini berdasarkan kebutuhan itik petelur periode layer (Balitnak, 2006).

Pelaksanaan pelatihan menekankan kepada mitra agar prinsip-prinsip dasar yang disampaikan dalam whorkshop harus dikuasai oleh mitra yaitu jenis-jenis bahan pakan yang dapat diberikan pada ternak khususnya itik dan ayam kampung. Hal ini karena akan menentukan keberhasilan dalam usaha peternakannya, terutama keberhasilan 
produksi telur dan daging yang dihasilkan. Hasil dari ransum yang telah dibuat tidak langsung diberikan pada itik, tapi terlebih dahulu dicampur dengan air sampai menjadi pasta. Metode lain dalam pemberian ransum pada itik dengan cara dikukus (steam), Hal ini menyebabkan ransum lebih mudah dicerna dan diserap, sehingga dapat menghasilkan produksi telur dan daging itik yang lebih tinggi (Saelan E., 2017). Pengolahan bahan pakan dengan cara pengukusan (steam) memiliki keutungan dapat mengurangi jumlah kandungan nutrisi yang hilang karena bahan pakan tidak langsung bersentuhan dengan air (Susangka et al.,2006). Pengolahan dengan teknik pengukusan adalah teknik pengolahan pakan melibatkan uap panas dan teknik penggunaan panas bervariasi tergantung karateristik ransum yang diharapkan, Ransum hasil pengukusan adalah pada prinsipnya untuk meningkatkan produktivitas dalam usaha ternak itik, kaitannya dengan biaya produksi yang dibutuhkan dan hasil akhir yang diperoleh, sehingga dapat memperbaiki konversi ransum, efisiensi pakan dan nutrient availability (Ersoy and Ozeren, 2009).

\section{Pengolahan Ransum Unggas}

Pengolahan ransum unggas khususnya untuk ternak itik dilakukan dengan metode pengolahan secara fisik yaitu dengan pengukusan. Pakan yang telah diformulasi sebelum diberikan pada ternak itik dilakukan pengukusan selama 20 menit. Pengukusan menyebabkan terjadinya gelatinisasi pati sehingga ikatan-ikatan kompleks penyusun bahan pakan menjadi sederhana (polisakarida menjadi oligosakarida, dan monosakarida) renggang. Aktifitas enzim pencernaan selulase dan amilase meningkat, protein dan karbohidrat lebih mudah dicerna dan diserap (Saelan E., 2017).

Pengukusan (steaming) adalah model dan metoda pengolahan menggunakan panas lembab (moist heat). Pemasakan dengan panas lembab menyebabkan terjadinya perpindahan panas secara konveksi dari uap panas ke ransum atau bahan makanan yang dikukus. Studi tentang pengukusan dilakukan oleh Skoch (1981), yang disitasi oleh Behnke (2001) dengan membuat percobaan yang membandingkan antara pembuatan pellet dengan pengukusan dan secra kering. Hasilnya menunjukkan pengukusan mempengaruhi ketahanan, meningkatkan konsumsi pakan dan kecernaannya. Uap yang bersirkulasi menimbulkan terbentuknya penyatuan bahan-bahan pakan, dan keseluruhan bahan pakan meleleh secara bersamaan dan akhirnya terjadi penyatuan diantara bahan pakan tersebut, sehingga tekstur ransum menjadi lunak dan matang (Saelan E., 2017).

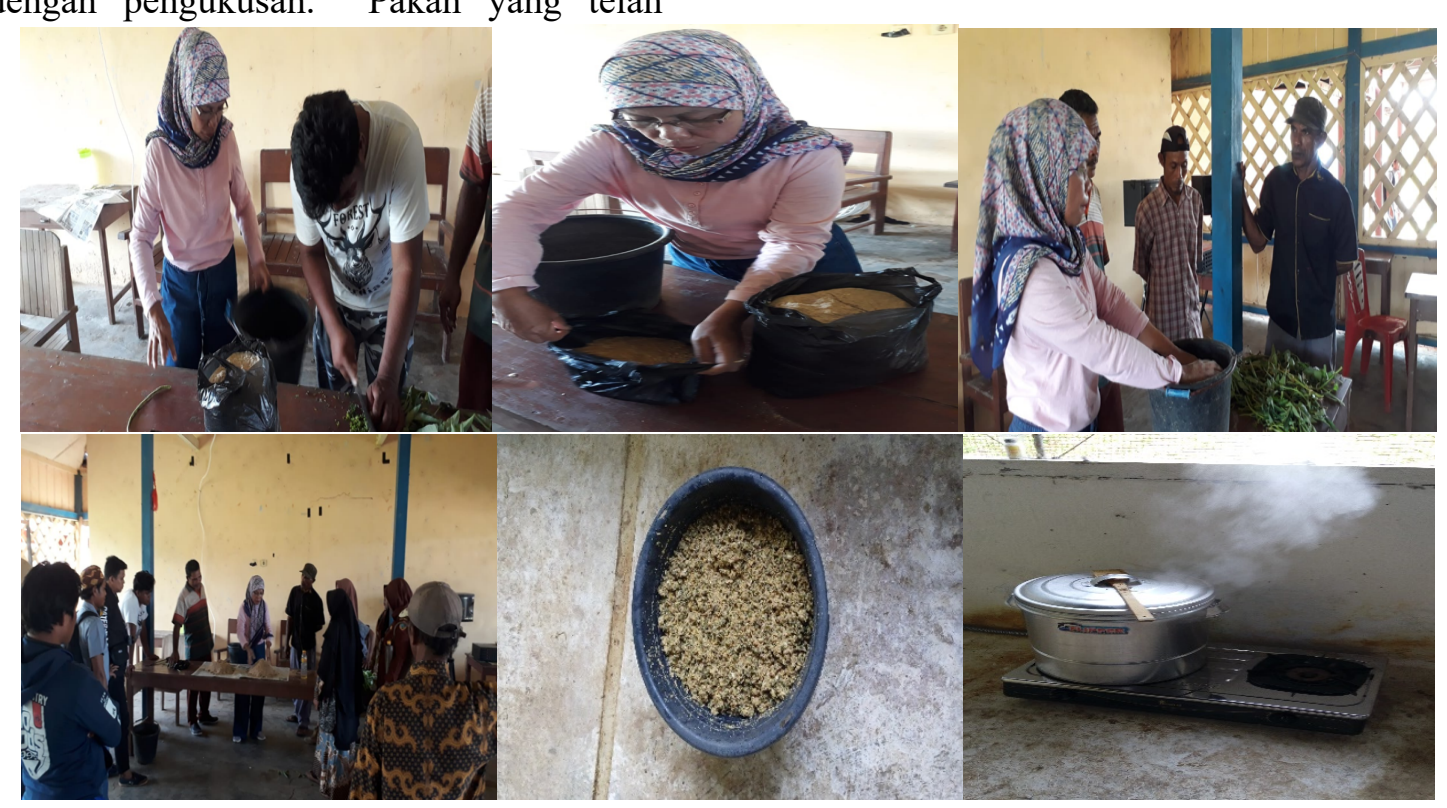

Gambar 4. Pengolahan Ransum Secara Fisik dengan Metode Pengukusan 


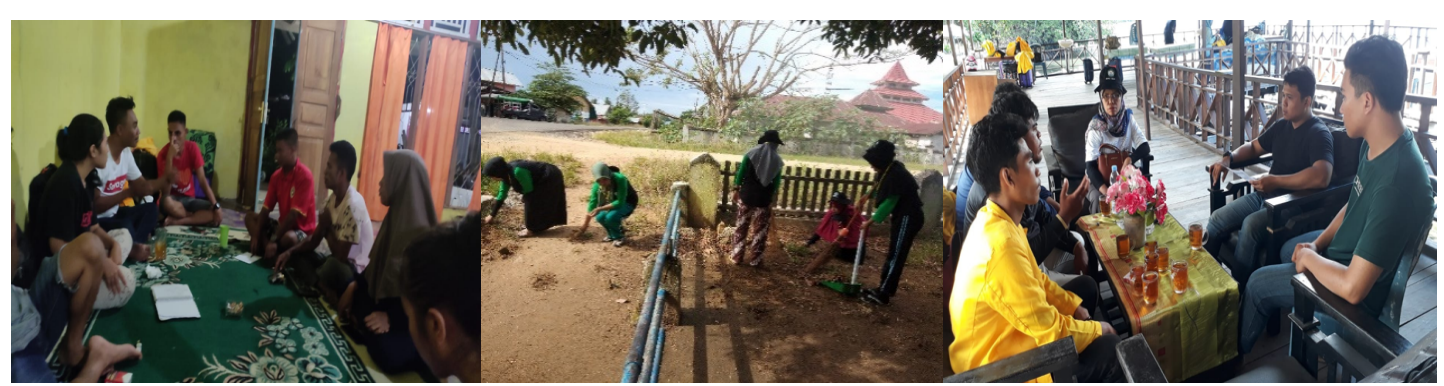

Gambar 5. Monitoring dan Evaluasi Kegiatan PKM Kubermas Tematik

\section{Monitoring dan Evaluasi}

Monitoring dilakukan dengan tujuan melakukapenilaian dan pangamatan terhadapat program kerja mahasiswa peserta Kubermas Tematik. Kegiatan yang dilakukan selama monitoring berupa pengumpulan data dan penilaian terhadap program kerja yang dilaksanakan peserta mahasiswa Kubermas Tematik. Pelaksanaan kegiatan monitoring selain dilakukan oleh Dosen Pendamping Lapangan (DPL) juga dilakukan oleh Aparat Desa setempat serta masyarakat yang dilokasi kegiatan Kubermas Tematik.

Evaluasi dilakukan untuk melihat keberhasilan pelaksanaan program kerja dimasyarakat baik secara individu maupun secara kelompok. Evaluasi juga dilakukan untuk melihat program kerja yang tingkat keberhasilannya masih belum sempurna, sehingga dapat dilakukan perbaikan secepatnya sebelum berakhirnya pelaksanaan Kubermas Tematik. Penilaian dalam pelaksanaan Kubermas Tematik dilakukan secara individu, sehingga dalam pelaksanaan program kerja setiap individu harus berperan aktif.

\section{Kesimpulan}

Pelatihan pembuatan ransum unggas menggunakan bahan pakan lokal memberikan pengaruh positif pada peternak yaitu terbentuknya dua kelompok ternak unggas yang menjadi kelompok ternak binaan. Peternak tidak lagi tergantung pada ransum pabrikan, karena peternak sudah memiliki keterampilan dan menyusun dan meramu pakan lokal yang tersedia menjadi ransum unggas khususmya itik dan ayam kampung. Kelompok ternak mitra yang sudah terbentuk harus mempunyai tempat penyimpangan produksi pakan sehingga menjadi peluang bagi peternak sebagai penyedia pakan bagi desa lainnya yang ada di Kabupaten Halmahera Tengah.

\section{Ucapan Terima Kasih}

Ucapan terima kasih penulis sampaikan kepada Universitas Khairun atas Pendanaan dalam pelaksanaan PKM Kubermas Tematik.

\section{Daftar Pustaka}

Anggorodi, R. 1995. Ilmu Pakan Ternak Umum. Gramedia Pustaka Utama. Jakarta

Behnke, KC. 2001. Factor Influencing Pelleting Quality. Departemen of Grain Science and Industry. Kansas University. Kansas.

[BPS] Badan Pusat Statistika, 2017. Halmahera Tengah Dalam Angka

[BPS] Badan Pusat Statistika, 2018. Halmahera Tengah Dalam Angka

[BPS] Badan Pusat Statistika, 2019. Halmahera Tengah Dalam Angka

[Balitnak] Balai Penelitian Ternak. 2006. Pendatang baru penghasil telur: Itik $M A$. Bogor: Unit Komersialisasi Teknologi Balitnak. www.balitnak.litbang.deptan.go.id.

Ersoy, B. Ozeren A. 2009. The Effect of Cooking Methods on Mineral and Vitamin Contents of African Catfish. Food Chemistry. $115:$ 419-422.

Ichwan, W. M. 2003. Membuat Pakan Ayam Ras Pedaging. Agromedia Pustaka. Jakarta. 
Jahan, M.S., M. Asaduzzaman and A.K. Sarkar. 2006. Performance Feed on Mash, Pellet and Crumble. International Journal of Poultry Science. 5(3):265-270.

Susangka, Hariyani, Andriyani. 2006. Evaluasi Nilai Gizi Limbah Sayuran Produk Cara Pengolahan Berbeda dan Pengaruhnya Terhadap Pertumbuhan Ikan Nila. Di dalam Laporan Penelitian. Bandung: Universitas Padjadjaran.

Saelan E, 2017. Aplikasi Teknogi Pengukusan Ransum Bentuk Mash Sebagai Upaya Memperbaiki Lingkungan Kandang dan Performa
Produksi Itik Petelur. Disertasi Universitas Padjadjaran.

North, M. O. 1978. Commercial Chicken Production Manual. Second Edition. The Avi Publishing Company, Inc. Westport, Connecticut.

Rusmana D, Abun, Saefulhadjar D, 2007. Pengaruh Pengolahan Limbah Sayuran secara Mekanis terhadap Kecernaan dan Efisiensi Penggunaan Protein pada Ayam Kampung Super. Jakarta. LIPI.

Wahju, J. 2004. Ilmu Nutrisi Unggas. Cetakan Kelima. Gadjah Mada University Press. Yogyakarta 